\title{
Situation A, potentiality B, lovelorn C
}

I 've looked at friends who have devoted their lives to writing and felt utterly sapped. I've romanticized their lives, imagining them howling at their vicious muses at $2 \mathrm{am}$. These friends of mine are poets and novelists and all of them are fine writers. They'd be embarrassed if I named them, but, to a one, they are creatively tenacious. I used to believe they operated on a simple principle: how will situation $\mathrm{A}$ or potentiality $\mathrm{B}$ help my art?

Now I know it's not so simple.

I can be forgiven for thinking that way. I'd be post-call and about to hit bed, when a poet would phone, telling me about his I2-hour struggle with a single line of poetry that was revealed to be, after I inquired, 6 words long. One of those words was "a."

At that point I had been trying to write and mostly failing for lack of time, and when there was time, for lack of energy. My friends were writing and getting published, but more importantly they were developing as artists, and so artist-envy settled in: I developed as a physician, but stayed static as a writer, and resented anyone who had the opportunity to write. (As if writing could be phrased like an equal-opportunity program.)

Yet I knew that occupations tend to be the culmination of a long series of calculated choices; I didn't just materialize as a doctor, I aspired to become one. And those writers whose "opportunities" I coveted were also the product of a culmination of a series of choices, some very difficult. One of my writer friends was destitute and somewhat mad and had sacrificed many, many relationships for his "opportunity." He would often, and sincerely, tell me how lucky I was to be someone for whom writing is an avocation and not a voca-

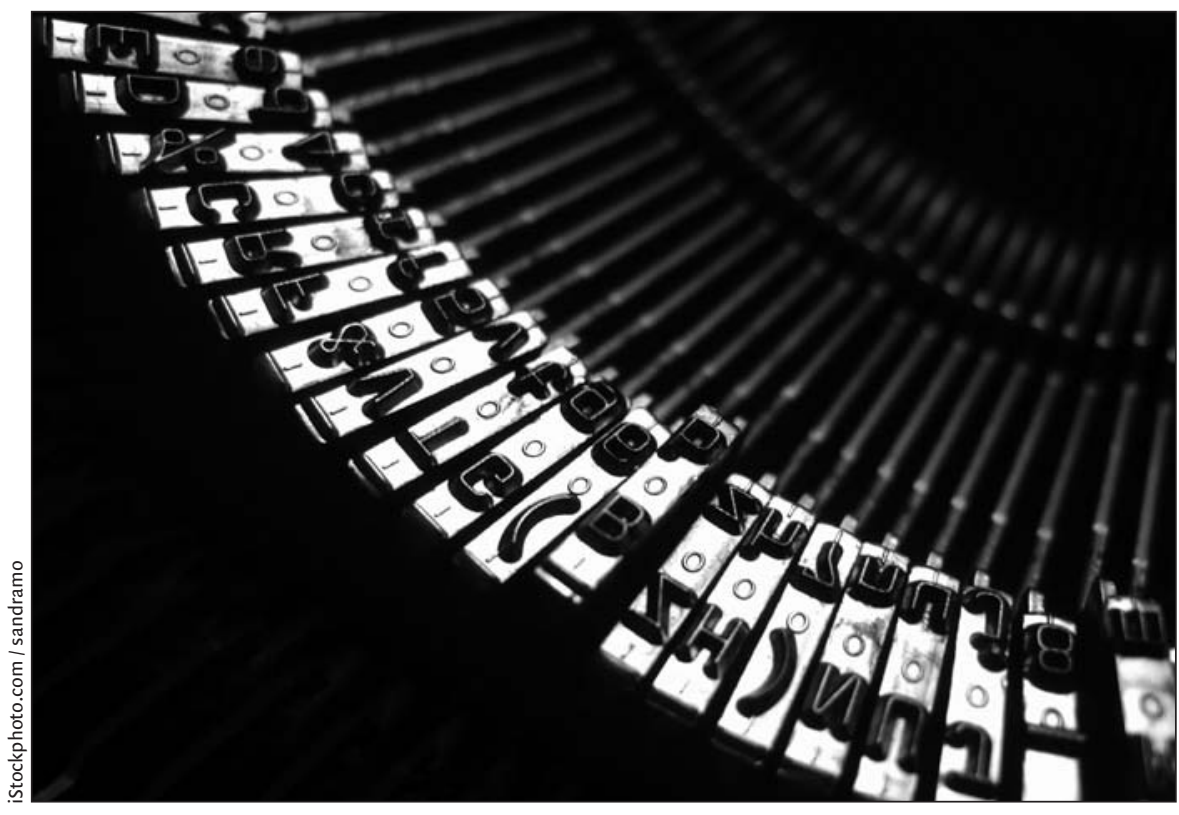

tion, a choice and not a compulsion. What he meant was that he could do nothing else, or perhaps would do nothing else, and he resented the fact that I had options, or perhaps that there was small likelihood that my family would ever go hungry, that my children would fail to have the "opportunity" to go to university, etc.

We want what we do not have. I wanted to be a full-time writer and I intuited that he wanted to be a full-time other. But it's more complicated than that. Do we want what we cannot have, what is in our nature not to have? This man was unstable, instability was his locus; was he coveting what he denied to himself? Likewise, was I, in moaning about no time to write, actually being disrespectful of the choices I had made?

It's easy to argue for the doctor life. My writer friends are poor, living on the sporadic income of grant money and, when they get hungry enough, the meagre remuneration of menial jobs. But they write, and write well; they have no need to husband their strength and pick their moment. And when I read their work, I fall in love with the choice they have made. When I read what I have scribbled, I think: don't quit your day job. The truth is: I can't.

But neither can they. And the truth for them is that they have to make a choice as to what to deny, what to refuse, what to prevent from entering their lives, to clear room for writing. We share this, though by different methods: I jettison, they insulate. There are costs to both, and so writing need not be romanticized. The muse isn't vicious, the lifestyle is. Situation A or potentiality B may not help art, not much does, but it certainly may help one's life.

Shane Neilson MD

Family physician

Guelph, Ont. 